\title{
Dual Substrate Specificity of Bacillus subtilis PBP4a
}

\author{
Venkatesh V. Nemmara, ${ }^{\dagger}$ S. A. Adediran, ${ }^{\dagger}$ Kinjal Dave, ${ }^{\dagger}$ Colette Duez, ${ }^{\ddagger}$ and R. F. Pratt*, ${ }^{\dagger}$ \\ ${ }^{\dagger}$ Department of Chemistry, Wesleyan University, Lawn Avenue, Middletown, Connecticut 06459, United States \\ ${ }^{\ddagger}$ Centre d’Ingéniere des Protéines, Université de Liège, B-4000 Sart Tilman, Liège, Belgium
}

\section{Supporting Information}

ABSTRACT: Bacterial DD-peptidases are the targets of the $\beta$-lactam antibiotics. The sharp increase in bacterial resistance toward these antibiotics in recent years has stimulated the search for non- $\beta$-lactam alternatives. The substrates of DD-peptidases are elements of peptidoglycan from bacterial cell walls. Attempts to base DD-peptidase inhibitor design on peptidoglycan structure, however, have not been particularly successful to date because the specific substrates for most of these enzymes are unknown. It is known, however, that the preferred substrates of low-molecular mass (LMM) class B and C DD-peptidases contain the

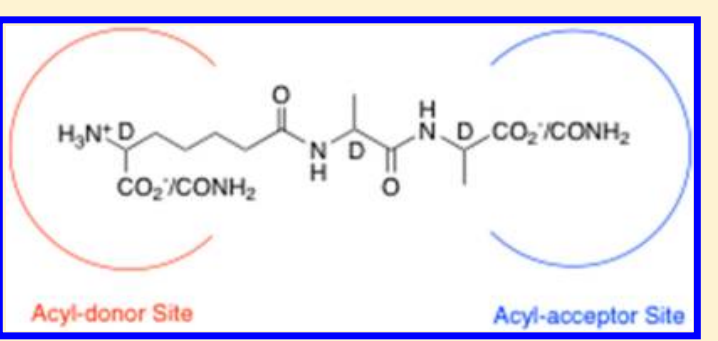
free N-terminus of the relevant peptidoglycan. Two very similar LMMC enzymes, for example, the Actinomadura R39 DDpeptidase and Bacillus subtilis PBP4a, recognize a D- $\alpha$-aminopimelyl terminus. The peptidoglycan of $B$. subtilis in the vegetative stage, however, has the N-terminal D- $\alpha$-aminopimelyl carboxylic acid amidated. The question is, therefore, whether the DDpeptidases of $B$. subtilis are separately specific to carboxylate or carboxamide or have dual specificity. This paper describes an investigation of this issue with $B$. subtilis PBP4a. This enzyme was indeed found to have a dual specificity for peptide substrates, both in the acyl donor and in the acyl acceptor sites. In contrast, the R39 DD-peptidase, from an organism in which the peptidoglycan is not amidated, has a strong preference for a terminal carboxylate. It was also found that acyl acceptors, reacting with acyl-enzyme intermediates, were preferentially D-amino acid amides for PBP4a and the corresponding amino acids for the R39 DD-peptidase. Examination of the relevant crystal structures, aided by molecular modeling, suggested that the expansion of specificity in PBP4a accompanies a change of Arg351 in the R39 enzyme and most LMMC DD-peptidases to histidine in PBP4a and its orthologs in other Bacillus sp. This histidine, in neutral form at $\mathrm{pH} 7$, appeared to be able to favorably interact with both carboxylate and carboxamide termini of substrates, in agreement with the kinetic data. It may still be possible, in specific cases, to combat bacteria with new antibiotics based on particular elements of their peptidoglycan structure.

DD-Peptidases catalyze the final step(s) in bacterial cell wall biosynthesis. These enzymes, therefore, are important antibiotic targets and do, in fact, represent the site of action of the $\beta$ lactams. ${ }^{1,2}$ They are known to catalyze the peptidoglycan crosslinking reaction of Scheme 1, an amide aminolysis (trans-

\section{Scheme 1}

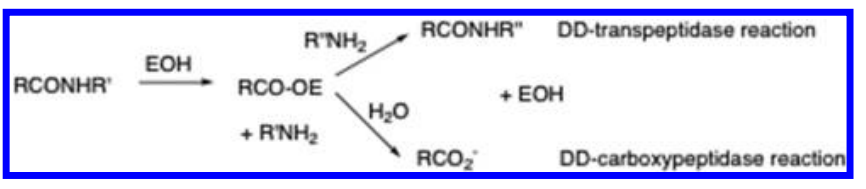

peptidase) reaction involving a covalent acyl-enzyme intermediate. Although it is clear that the substrates of these enzymes must be elements of peptidoglycan, the source of their individual specificity is, in general, not understood. ${ }^{3,4}$

The issue is complicated by the presence in bacteria of a variety of DD-peptidases with apparently different roles in cell wall construction, and acting at different times in the cell cycle. ${ }^{5,6}$ They are usually subdivided into a high-molecular mass (HMM) group, with subclasses A and B, and a low-molecular mass (LMM) group, with subclasses $\mathrm{A}-\mathrm{C}$. $^{7}$ The former act as transpeptidases (Scheme 1), are essential to bacterial survival, and represent the killing sites of the $\beta$-lactam antibiotics. The LMM group is believed to contain carboxypeptidases and endopeptidases, which are engaged in peptidoglycan maturation and degradation and are nonessential to bacterial survival, in the short term at least, although they are also inhibited by $\beta$ lactams.

A representative example of general peptidoglycan structure (stem peptide dimer) is shown in Figure 1. In this figure, $\mathbf{1}$ represents a peptidoglycan dimer and (a) and (b) represent the two structural variants, carboxylate and carboxamide, discussed in detail below. One might imagine that the DD-peptidases would show some recognition of elements of this structure. The results of experiments conducted in vitro with individual purified DD-peptidases are decidedly ambivalent overall. ${ }^{3}$ In general, purified HMM DD-peptidases show no significant affinity for any part of $\mathbf{1}$ or catalyze any reaction of it at biologically significant rates. Certain LMMA DD-peptidases catalyze the carboxypeptidase reaction of D-alanine-terminating peptides but, in general, show no significant affinity for any part of 1. LMMB and LMMC enzymes, however, have been shown

Received: February 18, 2013

Revised: March 25, 2013

Published: April 5, 2013 


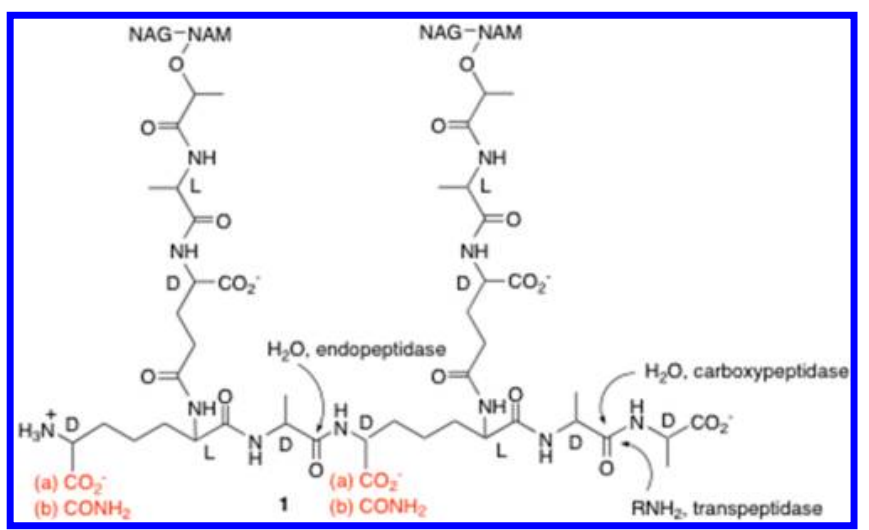

Figure 1. Stem peptide dimer of B. subtilis showing the sites of amidation and DD-peptidase cleavage. The structural variants addressed in this paper are (a) carboxylate and (b) carboxamide.

to exhibit strong affinity for the stem peptide N-terminus appropriate to the particular organism from which they were derived. $^{4,8,9}$ This result is seen in the kinetics of turnover of specific peptide substrates and the affinity of specific inhibitors such as $\beta$-lactams and boronic acids. The structural bases of these specificities have been revealed by crystal structures of various complexes of the enzymes with these compounds. ${ }^{10-12}$

One LMMC DD-peptidase in which these issues have been studied in some detail is PBP4a of Bacillus subtilis. This enzyme has been shown to have considerable specificity toward peptide $2\left(k_{\mathrm{cat}} / K_{\mathrm{m}}=2.2 \times 10^{4} \mathrm{~s}^{-1} \mathrm{M}^{-1}\right)$ and is strongly inhibited by boronic acid $3\left(K_{\mathrm{i}}=9 \mathrm{nM}\right){ }^{4}$ The structural basis of this specificity has been revealed by crystallography. ${ }^{13}$

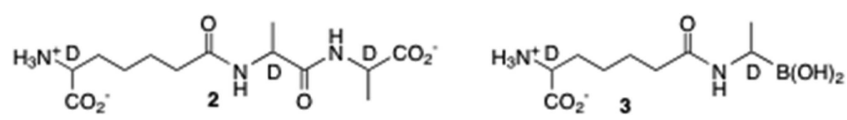

It has also been shown, however, that during the vegetative stage of growth, B. subtilis cell walls contain amidated mesodiaminopimelic acid, ${ }^{14,15}$ and thus, the peptidoglycan structure would be represented by $\mathbf{1 b}$. On the other hand, in B. subtilis spores, the predominant peptidoglycan is not amidated, as in 1a. ${ }^{16}$ Peptidoglycan containing amidated diaminopimelic acid is not uncommon and, in some cases, has established function. ${ }^{17}$ The actual in vivo role of $B$. subtilis PBP4a is not known, although it is apparently expressed in the late vegetative stage of growth $^{18}$ and thus, as an endopeptidase, may be faced with $\mathbf{1 b}$ as a substrate. On the other hand, if it is also active during construction of the spore wall, it might also be expected to hydrolyze 1a. The same issue must face other B. subtilis DDpeptidases or penicillin-binding proteins (PBPs). B. subtilis carries an extensive array of PBPs, some devoted to the vegetative stage and others expressed during spore formation. ${ }^{19}$ The specificity of these enzymes for amidated versus nonamidated peptidoglycan is, in general, not known. In this paper, we explore the specificity of $B$. subtilis PBP4a for the specific amidated acyl-donor and acyl-acceptor substrates $\mathbf{4}$ and $\mathbf{5}$, as expressed in steady state kinetics. The analogy of the latter substrate to an amidated penicillin is also explored.

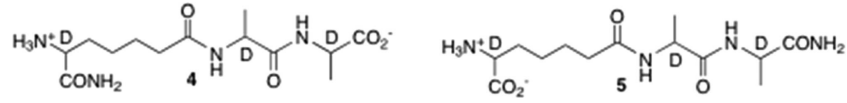

\section{MATERIALS AND METHODS}

D-Amino acids and D-amino acid amides were commercial products (Sigma, ChemImpex) and used as received, except Dlysinamide, which was prepared as described in the Supporting Information. The synthesis of $\mathbf{2}$ in this laboratory has been previously described. ${ }^{20}$ Penicillin V (phenoxymethylpenicillin) was purchased from Sigma and its amide synthesized in this laboratory according to the method of Johnson ${ }^{21}$ by E. Baukanas. N-(Phenylacetyl)glycyl-D-thiolactate was synthesized as previously described. ${ }^{22}$

Synthesis. The synthesis of $\mathbf{4}$ is outlined in Scheme 2, and the experimental details are given below.

D-6-(N,N-Dibenzylamino)-6-(benzyloxycarbonyl)-transhex-2-enoic Acid Ethyl Ester (7). To a stirred solution of 6 $\left(2.84 \mathrm{~g}, 7 \mathrm{mmol}, 1\right.$ equiv) ${ }^{12}$ in dry THF $(20 \mathrm{~mL}$ ) (under an inert atmosphere) was added (carbethoxymethylene)triphenylphosphorane ( $3.2 \mathrm{~g}, 9.2 \mathrm{mmol}, 1.3$ equiv) at room temperature. The reaction mixture was stirred for $4 \mathrm{~h}$, after which solvent was evaporated. The crude product was purified by chromatography on silica gel (9.5:0.5 hexane:ethyl acetate), yielding the product 7 as a colorless oil $(1.62 \mathrm{~g}, 60 \%$ yield $):{ }^{1} \mathrm{H}$ NMR $\left(\mathrm{CDCl}_{3}, 300 \mathrm{MHz}\right) \delta 1.27(\mathrm{t}, J=6.9 \mathrm{~Hz}, 3 \mathrm{H}), 1.86(\mathrm{~m}$, $2 \mathrm{H}), 2.05(\mathrm{~m}, 1 \mathrm{H}), 2.32(\mathrm{~m}, 1 \mathrm{H}), 3.35(\mathrm{t}, J=7.5 \mathrm{~Hz}, 2 \mathrm{H}), 3.50$, $3.88(\mathrm{AB} \mathrm{q}, J=15 \mathrm{~Hz}, 4 \mathrm{H}), 4.15(\mathrm{q}, J=7.2 \mathrm{~Hz}, 2 \mathrm{H}), 5.16,5.26$ $(\mathrm{AB} \mathrm{q}, J=10.8 \mathrm{~Hz}, 2 \mathrm{H}), 5.62(\mathrm{~d}, J=16 \mathrm{~Hz}, 1 \mathrm{H}), 6.75$ (quint, $J$ $=7.2 \mathrm{~Hz}, 1 \mathrm{H}), 7.2-7.45(\mathrm{~m}, 15 \mathrm{H})$.

D- $\alpha$-Aminopimelic Acid Ethyl Ester (8). To a solution of 7 $(1.02 \mathrm{~g}, 2.3 \mathrm{mmol}, 1.0$ equiv) in a mixture of methanol $(30 \mathrm{~mL})$ and ethyl acetate $(5 \mathrm{~mL})$ was added $10 \% \mathrm{Pd}$ on activated carbon $(\mathrm{Pd} / \mathrm{C})(260 \mathrm{mg})$. The hydrogenation reaction was conducted at $50 \mathrm{psi}_{2}$ at room temperature for $16 \mathrm{~h}$. Pd/C was removed by filtration through a Celite pad. The filtrate was evaporated leaving behind an off-white solid, which was dried under reduced pressure to give $8(335 \mathrm{mg}, 78 \%):{ }^{1} \mathrm{H}$ NMR $\left(\mathrm{CD}_{3} \mathrm{OD}, 300 \mathrm{MHz}\right) \delta 1.21(\mathrm{t}, J=6.9 \mathrm{~Hz}, 3 \mathrm{H}), 1.42(\mathrm{~m}, 2 \mathrm{H})$, $1.62(\mathrm{~m}, 2 \mathrm{H}), 1.80(\mathrm{~m}, 2 \mathrm{H}), 2.34(\mathrm{t}, J=7.5 \mathrm{~Hz}, 2 \mathrm{H}), 3.5(\mathrm{~m}$, $1 \mathrm{H}), 4.2(\mathrm{q}, J=7.2 \mathrm{~Hz}, 2 \mathrm{H})$.

(Z)-D- $\alpha$-Aminopimelic Acid Ethyl Ester (9). To a stirred solution of 8 and $\mathrm{Na}_{2} \mathrm{CO}_{3}$ in a water/dioxane (1:1) mixture (20 $\mathrm{mL})$ at ice temperature was added benzyl chloroformate $(0.35$ $\mathrm{mL}, 3.3 \mathrm{mmol}, 2.0$ equiv) in dioxane $(3 \mathrm{~mL})$ dropwise over 10 min. The reaction mixture was then brought to room temperature and stirred overnight. The mixture was extracted with ether $(3 \times 20 \mathrm{~mL})$, and the $\mathrm{pH}$ of the aqueous layer was adjusted to 1.0 by addition of $1.0 \mathrm{M} \mathrm{HCl}$. The acidified layer was extracted with ethyl acetate $(5 \times 50 \mathrm{~mL})$ and separated. The combined organic layers were dried over $\mathrm{Na}_{2} \mathrm{SO}_{4}$ and evaporated to dryness. The residue was dried further under reduced pressure, and the resulting sticky gum was purified by column chromatography on silica gel (4:3 hexane:ethyl acetate) to yield 9 as a colorless oil $(0.5 \mathrm{~g}, 95 \%$ yield $):{ }^{1} \mathrm{H}$ NMR $\left(\mathrm{D}_{6-}\right.$ DMSO, $300 \mathrm{MHz}) \delta 1.16(\mathrm{t}, J=7.2 \mathrm{~Hz}, 3 \mathrm{H}), 1.31(\mathrm{~m}, 2 \mathrm{H})$, $1.49(\mathrm{~m}, 2 \mathrm{H}), 1.65(\mathrm{~m}, 2 \mathrm{H}), 2.26(\mathrm{t}, J=7.5 \mathrm{~Hz}, 2 \mathrm{H}), 3.9(\mathrm{~m}$, $1 \mathrm{H}), 4.02(\mathrm{q}, J=7.5 \mathrm{~Hz}, 2 \mathrm{H}), 5.05(\mathrm{~s}, 2 \mathrm{H}), 7.35$ (s, $5 \mathrm{H}), 7.6$ (d, $J=8.1 \mathrm{~Hz}, 2 \mathrm{H})$.

D-6-Benzyloxycarbonylamino-6- $\left[N-\left(2^{\prime}, 4^{\prime}\right.\right.$ dimethoxybenzyl)carbamoyl]hexanoic Acid Ethyl Ester (10). Compound 9 ( $0.5 \mathrm{~g}, 1.48 \mathrm{mmol}, 1.0$ equiv) in DMF (12 mL) was added by syringe into a round-bottom flask containing HATU ( $0.76 \mathrm{~g}, 2.0 \mathrm{mmol}, 1.35$ equiv) maintained under a nitrogen atmosphere with constant stirring. The flask was cooled with ice, and 2,4-dimethoxybenzylamine $(0.3 \mathrm{~mL}, 2.0$ 
Scheme 2

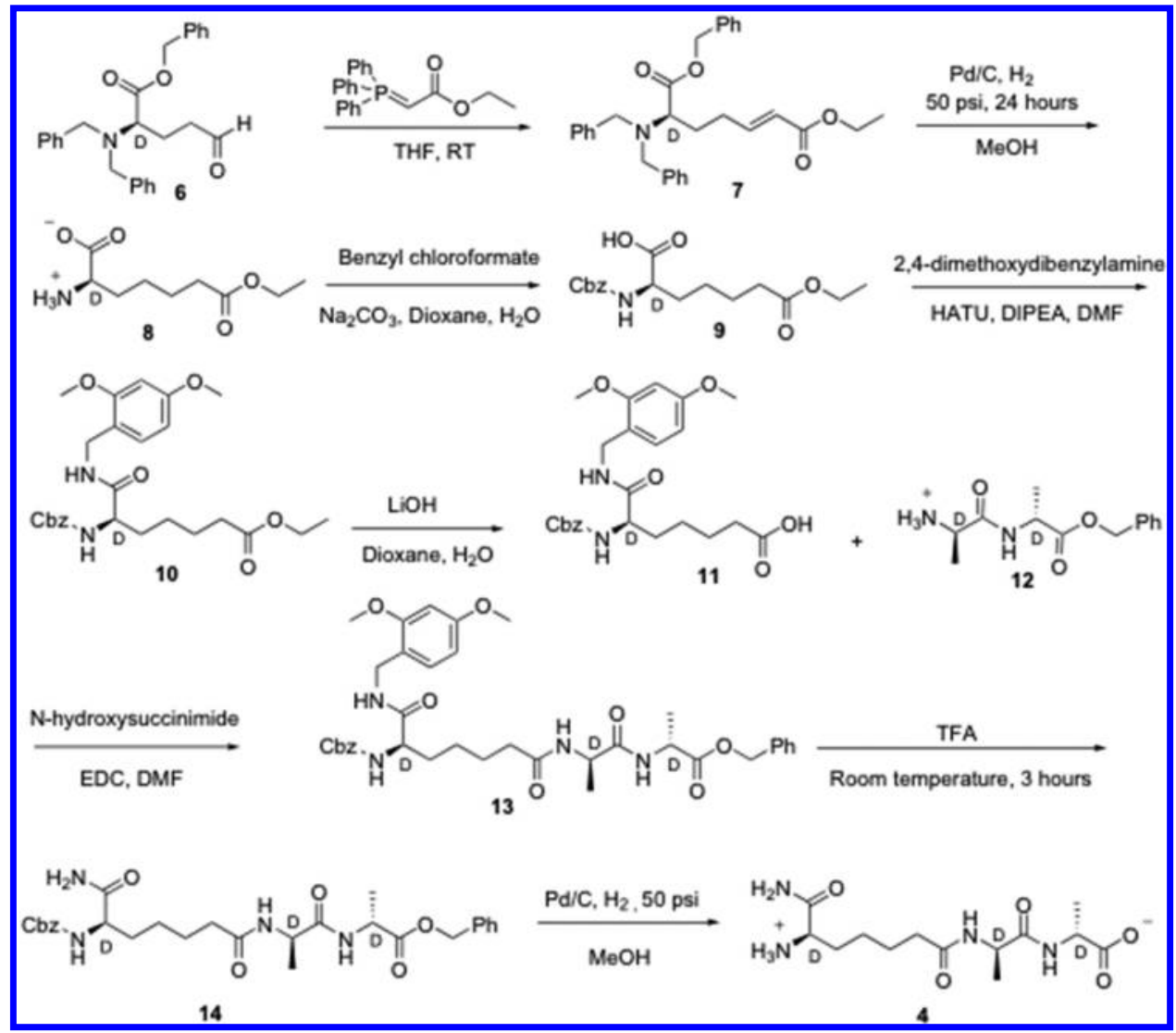

mmol, 1.35 equiv) was added. DIPEA (0.64 mL, $3.7 \mathrm{mmol}, 2.5$ equiv) was then added dropwise over $20 \mathrm{~min}$. The reaction mixture was subsequently brought to room temperature and stirred overnight. The solvent, DMF, was removed by rotary evaporation, and the residue was extracted with ethyl acetate. This solution was washed with $0.1 \mathrm{M} \mathrm{HCl}(20 \mathrm{~mL})$, water, and finally brine. The organic layer was separated, dried over $\mathrm{Na}_{2} \mathrm{SO}_{4}$, and evaporated to dryness. The residual yellow oil was purified by column chromatography on silica gel (3:7 hexane:ethyl acetate) to yield 10 as a colorless solid (440 mg, $70 \%$ yield): ${ }^{1} \mathrm{H}$ NMR (D ${ }_{6-}$ DMSO, $\left.300 \mathrm{MHz}\right) \delta 1.16(\mathrm{t}, J=7.2$ $\mathrm{Hz}, 3 \mathrm{H}), 1.23(\mathrm{~m}, 2 \mathrm{H}), 1.49(\mathrm{~m}, 2 \mathrm{H}), 1.65(\mathrm{~m}, 2 \mathrm{H}), 2.26(\mathrm{t}, J=$ $7.5 \mathrm{~Hz}, 2 \mathrm{H}), 3.73(\mathrm{~s}, 3 \mathrm{H}), 3.76(\mathrm{~s}, 3 \mathrm{H}), 3.9(\mathrm{~m}, 1 \mathrm{H}), 4.02(\mathrm{q}, J$ $=7.2 \mathrm{~Hz}, 2 \mathrm{H}), 4.15(\mathrm{~m}, 2 \mathrm{H}), 5.02(\mathrm{~s}, 2 \mathrm{H}), 6.45(\mathrm{~d}, J=7.8$ $\mathrm{Hz}, 1 \mathrm{H}), 6.53$ (s, $1 \mathrm{H}), 7.04$ (d, $J=8.4 \mathrm{~Hz}, 2 \mathrm{H}), 7.38(\mathrm{~m}, 5 \mathrm{H})$, $8.1(\mathrm{~m}, 1 \mathrm{H}) ; \mathrm{ESI} / \mathrm{MS}(+) \mathrm{m} / z 487.92(\mathrm{M}+1), 510.27(\mathrm{M}+$ 23).

D-6-Benzyloxycarbonylamino-6- [N- $\left(2^{\prime}, 4^{\prime}\right.$ dimethoxybenzyl)carbamoyl]hexanoic Acid (11). LiOH (17 $\mathrm{mg}, 0.7 \mathrm{mmol}, 1.0$ equiv) was added to compound 10 (340 mg, $0.7 \mathrm{mmol}, 1.0$ equiv) dissolved in a water/THF (1:1) mixture $(20 \mathrm{~mL})$ at $5{ }^{\circ} \mathrm{C}$. The reaction mixture was stirred at $5-10{ }^{\circ} \mathrm{C}$ until TLC showed complete conversion of the starting material. After completion of the reaction, THF was removed by evaporation and the $\mathrm{pH}$ of the aqueous layer adjusted to 1.0 by addition of 1.0 M HCl. The aqueous layer was then extracted with ethyl acetate $(4 \times 50 \mathrm{~mL})$ and separated. The combined organic layers were dried over $\mathrm{Na}_{2} \mathrm{SO}_{4}$ and evaporated to dryness. The crude product was purified by column chromatography on silica gel (9.3:0.7 DCM:MeOH) to yield 11 as a colorless solid (300 mg, 85\% yield): ${ }^{1} \mathrm{H}$ NMR ( $\mathrm{CD}_{3} \mathrm{OD}$,
$300 \mathrm{MHz}) \delta 1.34(\mathrm{~m}, 2 \mathrm{H}), 1.59(\mathrm{~m}, 2 \mathrm{H}), 1.60(\mathrm{~m}, 2 \mathrm{H}), 2.24$ $(\mathrm{t}, J=7.5 \mathrm{~Hz}, 2 \mathrm{H}), 3.76(\mathrm{~s}, 3 \mathrm{H}), 3.78(\mathrm{~s}, 3 \mathrm{H}), 4.05(\mathrm{~m}, 1 \mathrm{H})$, $4.3(\mathrm{~m}, 2 \mathrm{H}), 5.07(\mathrm{~s}, 2 \mathrm{H}), 6.43(\mathrm{~d}, J=7.8 \mathrm{~Hz}, 1 \mathrm{H}), 6.49(\mathrm{~s}$, $1 \mathrm{H}), 7.12$ (d, $J=8.4 \mathrm{~Hz}, 2 \mathrm{H}), 7.20$ (d, $J=7.8 \mathrm{~Hz}, 2 \mathrm{H}), 7.36$ $(\mathrm{m}, 5 \mathrm{H}), 8.1(\mathrm{~m}, 1 \mathrm{H})$; ESI/MS $(-) \mathrm{m} / z 457.00(\mathrm{M}-1)$.

D-6-Benzyloxycarbonylamino-6-[N- $\left(2^{\prime}, 4^{\prime}\right.$ dimethoxybenzyl)carbamoyl]hexanoyl-D-alanyl-D-alanine Benzyl Ester (13). To a solution of 11 (200 mg, $0.44 \mathrm{mmol}, 1.0$ equiv) in DMF ( $3 \mathrm{~mL}$ ) were added $N$-hydroxysuccinimide $(63$ $\mathrm{mg}, 0.55 \mathrm{mmol}, 1.25$ equiv) and 1-ethyl-3-[3-(dimethylamino)propyl]carbodiimide (105 mg, $0.55 \mathrm{mmol}, 1.25$ equiv) at ice temperature. The reaction mixture was brought to room temperature and stirred for $20 \mathrm{~h}$. To this mixture was added a solution of D-alanyl-D-alanine benzyl ester $12^{4}(0.24 \mathrm{~g}, 0.66$ mmol, 1.5 equiv) in DMF $(3 \mathrm{~mL})$ followed by the dropwise addition of DIPEA $(0.23 \mathrm{~mL}, 1.3 \mathrm{mmol}, 3.0$ equiv). The mixture was stirred overnight, after which DMF was removed by evaporation under vacuum. Water was added to the residue, and the solid formed was collected by filtration and dried under vacuum. The residual solid was recrystallized from 2-propanol to yield 13 as a colorless solid (170 mg, 58\% yield): ${ }^{1} \mathrm{H}$ NMR $\left(\mathrm{D}_{6-} \mathrm{DMSO}, 300 \mathrm{MHz}\right) \delta 1.07(\mathrm{~d}, J=6.9 \mathrm{~Hz}, 3 \mathrm{H}), 1.12(\mathrm{~d}, J=$ $6.9 \mathrm{~Hz}, 3 \mathrm{H}), 1.28(\mathrm{~m}, 2 \mathrm{H}), 1.43(\mathrm{~m}, 2 \mathrm{H}), 1.60(\mathrm{~m}, 2 \mathrm{H}), 2.06$ $(\mathrm{t}, J=6.8 \mathrm{~Hz}, 2 \mathrm{H}), 3.37(\mathrm{~s}, 3 \mathrm{H}), 3.39(\mathrm{~s}, 3 \mathrm{H}), 3.98(\mathrm{~m}, 1 \mathrm{H})$, $4.10(\mathrm{~m}, 1 \mathrm{H}), 4.3(\mathrm{~m}, 2 \mathrm{H}), 5.02(\mathrm{~s}, 2 \mathrm{H}), 5.10(\mathrm{~s}, 2 \mathrm{H}), 6.46(\mathrm{~d}, J$ $=8.4 \mathrm{~Hz}, 1 \mathrm{H}), 6.52(\mathrm{~s}, 1 \mathrm{H}), 7.04(\mathrm{~d}, J=8.4 \mathrm{~Hz}, 2 \mathrm{H}), 7.36(\mathrm{~m}$, $5 \mathrm{H}), 7.93(\mathrm{~d}, J=8.1 \mathrm{~Hz}, 1 \mathrm{H}), 8.1(\mathrm{~m}, 1 \mathrm{H}), 8.34(\mathrm{~d}, J=6.0 \mathrm{~Hz}$, $1 \mathrm{H}) ; \mathrm{ESI} / \mathrm{MS}(+) \mathrm{m} / z 691.0(\mathrm{M}+1), 713.43(\mathrm{M}+23)$.

$D$-6-Benzyloxycarbonylamino-6-carbamoylhexanoyl-Dalanyl-D-alanine Benzyl Ester (14). TFA (1.5 mL) was added to $13(40 \mathrm{mg}, 0.06 \mathrm{mmol})$ in a round-bottom flask at room 
temperature, and the solution was stirred for $3.5 \mathrm{~h}$. TLC monitoring confirmed the disappearance of the starting material. TFA was removed by evaporation, and the pink solid thus obtained was washed with ether until the pink color was completely removed. The crude product was purified by preparative TLC on silica gel with $7.5 \% \mathrm{MeOH}$ in DCM as the eluent, yielding 14 as a colorless solid $(28 \mathrm{mg}, 86 \%$ yield $):{ }^{1} \mathrm{H}$ $\operatorname{NMR}\left(\mathrm{CD}_{3} \mathrm{OD}, 300 \mathrm{MHz}\right) \delta 1.27(\mathrm{~d}, J=7.2 \mathrm{~Hz}, 3 \mathrm{H}), 1.37(\mathrm{~d}$, $J=7.5 \mathrm{~Hz}, 3 \mathrm{H}), 1.43(\mathrm{~m}, 2 \mathrm{H}), 1.61(\mathrm{~m}, 2 \mathrm{H}), 1.79(\mathrm{~m}, 2 \mathrm{H})$, $2.20(\mathrm{t}, J=6.9 \mathrm{~Hz}, 2 \mathrm{H}), 4.05(\mathrm{~m}, 1 \mathrm{H}), 4.31(\mathrm{~m}, 2 \mathrm{H}), 4.45(\mathrm{~m}$, $1 \mathrm{H}), 5.07$ (s, 2H), $5.14(\mathrm{~d}, J=5.4 \mathrm{~Hz}, 2 \mathrm{H}), 7.39(\mathrm{~s}, 10 \mathrm{H})$; ESI/ $\mathrm{MS}(+) m / z 541.0(\mathrm{M}+1), 563.40(\mathrm{M}+23)$.

D-6-Amino-6-carbamoylhexanoyl-D-alanyl-D-alanine (4). To a solution of $14(28 \mathrm{mg}, 0.05 \mathrm{mmol})$ in methanol (20 $\mathrm{mL})$ was added $10 \% \mathrm{Pd} / \mathrm{C}(10 \mathrm{mg})$. The hydrogenation reaction was conducted at $40 \mathrm{psi}_{2}$ at room temperature for 5 h. Pd/C was removed by filtration through a Celite pad. The filtrate was evaporated, leaving behind an off-white solid, which was dried under reduced pressure to give 4 (7 mg, 50\% yield): ${ }^{1} \mathrm{H} \operatorname{NMR}\left(\mathrm{D}_{2} \mathrm{O}\right) \delta 1.2(\mathrm{~m}, 6 \mathrm{H}), 1.30(\mathrm{~m}, 2 \mathrm{H}), 1.50(\mathrm{~m}, 2 \mathrm{H})$, $1.75(\mathrm{~m}, 2 \mathrm{H}), 2.16(\mathrm{t}, J=7 \mathrm{~Hz}, 2 \mathrm{H}), 3.85(\mathrm{t}, J=6.6 \mathrm{~Hz}, 1 \mathrm{H})$, $4.01(\mathrm{q}, J=7.6 \mathrm{~Hz}, 1 \mathrm{H}), 4.14(\mathrm{q}, J=7.6 \mathrm{~Hz}, 1 \mathrm{H})$; highresolution $\mathrm{ESI} / \mathrm{MS}(+) \mathrm{m} / z 317.1816(\mathrm{M}+1)$, calcd for $\mathrm{C}_{13} \mathrm{H}_{25} \mathrm{~N}_{4} \mathrm{O}_{5} 317.1825$.

Enzyme Kinetics. Steady state kinetics experiments were conducted under conditions previously established to generate high stable activity of Actinomadura R39 DD-peptidase and B. subtilis PBP4a: ${ }^{4} 20 \mathrm{mM}$ sodium phosphate $(\mathrm{pH} 7.5)$ at $25{ }^{\circ} \mathrm{C}$. Measurements of enzyme activity with peptides 4 and 5 were determined spectrophotometrically where the loss of the peptide bond was monitored at wavelengths between 215 and $235 \mathrm{~nm}$. Initial rates were fit to the Henri-MichelisMenten equation by a nonlinear squares procedure to yield values of $k_{\text {cat }}$ and $K_{\mathrm{m}}$. The range of peptide substrate concentrations employed was typically $0-1.0$ or $0-2.0 \mathrm{mM}$, and enzyme concentrations were typically $0.10-0.25 \mu \mathrm{M}$. In cases where substrate concentrations approaching $K_{\mathrm{m}}$ were not achieved, values of $k_{\text {cat }} / K_{\mathrm{m}}$ were obtained by nonlinear leastsquares exponential fits to the progress curve. In the case of the Actinomadura R39 DD-peptidase, the $K_{\mathrm{m}}$ of the peptide substrate 4 was determined as the $K_{\mathrm{i}}$ value from a competition experiment in which $N$-(phenylacetyl)glycyl-D-thiolactate, 15, was the spectrophotometric substrate $(245 \mathrm{~nm} ; \Delta \varepsilon=2500$ $\left.\mathrm{cm}^{-1} \mathrm{M}^{-1} ; K_{\mathrm{m}}=38.4 \mu \mathrm{M}\right)$. Kinetics of aminolysis of 15 by amino acids and amino acid amides were conducted as previously described. ${ }^{23}$ Rate constants of inactivation of the enzymes by the penicillins 16 and 17 were obtained from similar experiments where total progress curves were fit to Scheme 3 with Dynafit. ${ }^{24}$ Concentrations of enzyme, substrate (15), 16, and 17 in these experiments were $0.14 \mu \mathrm{M}, 0.5 \mathrm{mM}$,

\section{Scheme 3}

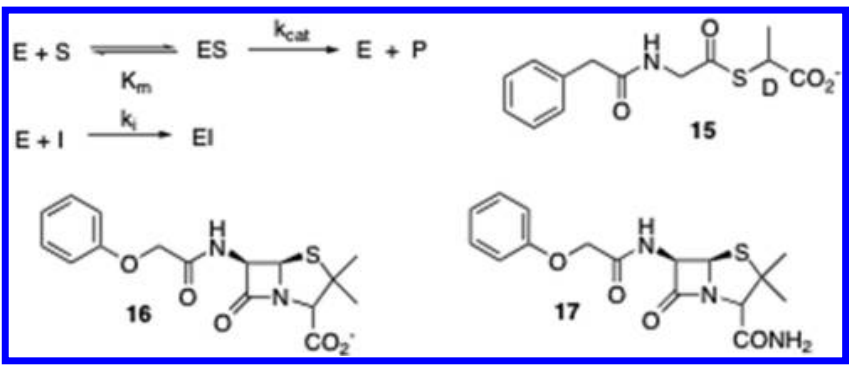

$0-0.30 \mu \mathrm{M}$, and $0-0.60 \mu \mathrm{M}$, respectively, for the $\mathrm{R} 39 \mathrm{DD}-$ peptidase and $0.17 \mu \mathrm{M}, 0.5 \mathrm{mM}, 0-0.10 \mu \mathrm{M}$, and $0-6.0 \mu \mathrm{M}$, respectively, for PBP4a. Compounds 20 and 21 were generated from the hydrolysis of $\mathbf{2}$ and 4, respectively, in the presence of $\mathrm{PBP} 4 \mathrm{a}$, and studied as inhibitors of this enzyme in situ as a function of $\mathrm{pH}$. Buffers for the latter experiments were $20 \mathrm{mM}$ MES (pH 6.0), $20 \mathrm{mM}$ MOPS (pH 7.5), and $20 \mathrm{mM}$ TAPS ( $\mathrm{pH} 8.8)$.

Computational Methods. Crystal structures of Actinomadura R39 DD-peptidase [Protein Data Bank (PDB) entry 2XDM] and B. subtilis PBP4a (PDB entry 2J9P) with specific ligands bound in the active site were used as the starting point for model building and computations with Discovery Studio version 2.5 (Accelrys). Tetrahedral intermediate structures of the enzyme-substrate reaction were modeled with D-alanine or D-alaninamide as the leaving group. A pH of 7.0 was set, with positive charge on Lys52 (R39) and Lys55 (PBP4a) and negative charge on Asp142 (Asp145), whereas His352 (PBP4a) was either charged or uncharged depending on the environment desired. The CHARMm force field was employed for all the computations.

In each case, the enzyme-substrate complex was hydrated with a $20 \AA$ sphere of water molecules centered at the active site serine. The hydrated structure was energy-minimized using a steepest descent algorithm (250 steps), followed by the conjugate gradient method for a total of 1000 steps. The energy-minimized structures were heated to $300 \mathrm{~K}$ in 10000 steps (10 ps) with coordinates saved every 100 steps. The output structure of the equilibration run was then subjected to a $1.0 \mathrm{~ns}$ production run at $300 \mathrm{~K}$. Several structures were selected from the output of each production run, and each of these was energy-minimized using the protocol mentioned above.

\section{RESULTS AND DISCUSSION}

The substrate specificity of bacterial DD-peptidases in terms of the structure of their presumed substrate, represented in Figure 1 , is a matter of considerable interest because of its relevance to antibiotic design. Considering the reactions catalyzed, transpeptidase, endopeptidase, and carboxypeptidase (Figure 1), and the general mechanism of the reaction (Scheme 1), it is clear that there are two elements of substrate specificity, that for the acyl donor and that for the acyl acceptor.

PBP4a of B. subtilis is a LMM class C DD-peptidase, thought likely to be an endopeptidase in vivo., ${ }^{45}$ The substrate specificity of this enzyme is particularly interesting because of the variable amidation of diaminopimelic acid exhibited in $B$. subtilis peptidoglycan, as described in the introductory section. To examine this issue, we first assessed the reactivity of PBP4a with substrates 2, 4, and 5. As a control, the Actinomadura R39 DD-peptidase, another LMMC enzyme, was employed; as far as we are aware, Actinomadura peptidoglycan does not contain amidated diaminopimelic acid.

The synthesis of $\mathbf{4}$ was achieved as outlined in Scheme 2. The orthogonally protected $\mathrm{D}-\alpha$-aminopimelic acid derivative 10 was obtained from the previously described versatile intermediate 6. The ethyl ester 10 was then hydrolyzed to produce the acid 11, which was coupled to D-alanyl-D-alanine benzyl ester 12, yielding the protected tripeptide 13. The carboxamide group of 13 , protected as an $\mathrm{N}$-(2,4-dimethoxybenzyl) derivative, ${ }^{26}$ was deprotected with trifluoroacetic acid and the remaining benzyl groups by hydrogenation to afford the required product 4 . The more straightforward synthesis of 5 


\section{Scheme 4}

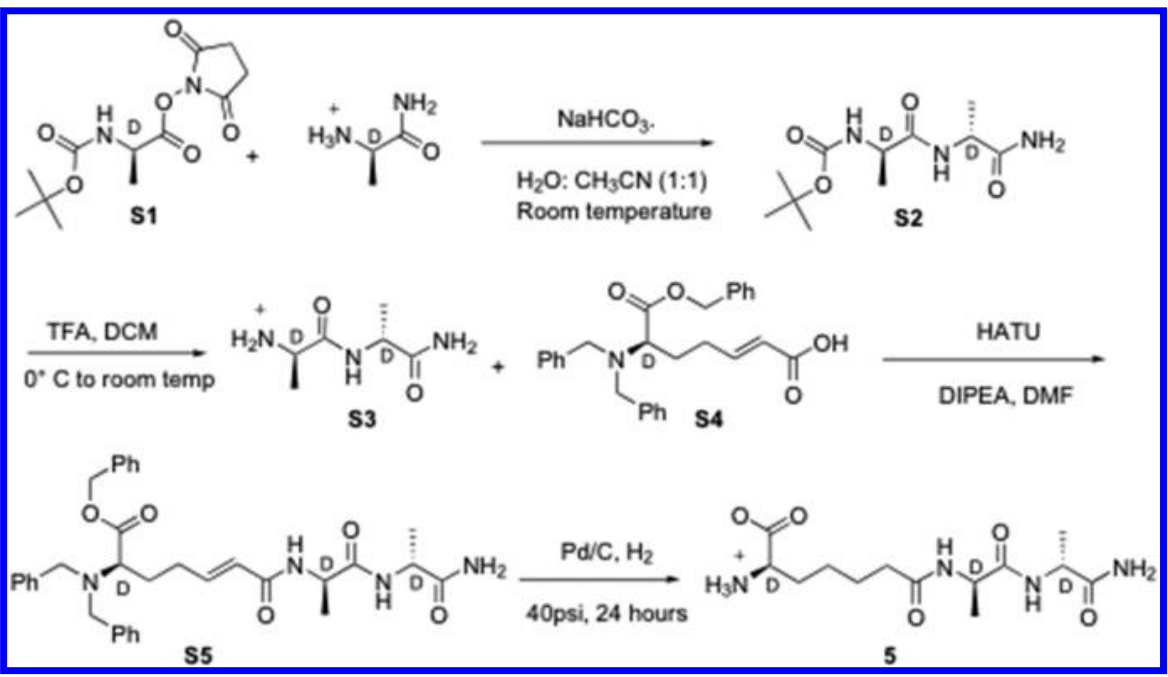

Table 1. Steady State Parameters for Peptide Hydrolysis by PBP4a and the R39 DD-Peptidase

\begin{tabular}{lll} 
enzyme & \multicolumn{1}{c}{ parameter } & \multicolumn{1}{c}{ substrate 2 } \\
PBP4a & $k_{\text {cat }}\left(\mathrm{s}^{-1}\right)$ & $\geq 22^{a}$ \\
& $K_{\mathrm{m}}(\mathrm{mM})$ & $\geq 1.0$ \\
& $k_{\text {cat }} / K_{\mathrm{m}}\left(\mathrm{s}^{-1} \mathrm{M}^{-1}\right)$ & $2.2 \times 10^{4}$ \\
& $\left(k_{\mathrm{cat}} / K_{\mathrm{m}}\right) /\left[k_{\mathrm{cat}} / K_{\mathrm{m}}(2)\right]$ & 1.0 \\
$\mathrm{R} 39$ & $k_{\text {cat }}\left(\mathrm{s}^{-1}\right)$ & $7.4 \pm 0.9^{c}$ \\
& $K_{\mathrm{m}}(\mathrm{mM})$ & $(1.3 \pm 0.5) \times 10^{-3}$ \\
& $k_{\text {cat }} / K_{\mathrm{m}}\left(\mathrm{s}^{-1} \mathrm{M}^{-1}\right)$ & $5.76 \times 10^{6}$ \\
& $\left(k_{\text {cat }} / K_{\mathrm{m}}\right) /\left[k_{\mathrm{cat}} / K_{\mathrm{m}}(2)\right]$ & 1.0
\end{tabular}

${ }^{a}$ From ref $13 .{ }^{b}$ From ref $4 .{ }^{c}$ From ref 20.

is outlined in Scheme 4 and described in detail in the Supporting Information.

Both the R39 DD-peptidase and PBP4a catalyzed hydrolysis of the C-terminal amino acid residue of 4 and 5, D-alanine and D-alaninamide, respectively, as demonstrated by electrospray mass spectra of completed reaction mixtures (not shown). Steady state rate parameters obtained from kinetics studies of this reaction are presented in Table 1 . These data show that the R39 enzyme is strongly specific for the diacid $\mathbf{2}$ with significantly less reactivity with the monoamides $\mathbf{4}$ and $\mathbf{5}$ and, in particular, with $\mathbf{5}$ where the amide would be in the acceptor site. The differences seem to be largely in the $K_{\mathrm{m}}$ parameter, suggesting differences in direct affinity for the active site, although it should be noted that whether acyl-enzyme intermediate formation or breakdown is rate-determining in the presence of saturating substrate is currently unknown. In the case of PBP4a, there is little difference in specificity for 2, 4, and 5, suggesting that carboxylate and amide react equally well in both sites. The common relatively high $K_{\mathrm{m}}$ is notably different from the situation with the R39 enzyme. It has been suggested that this reflects a need for a protein conformational change accompanying the reactions of PBP4a, perhaps deriving from the presence of unreactive conformers in solution. ${ }^{4}$ The striking difference in specificity for carboxylate versus amide substrates between the two enzymes is most readily seen in $k_{\text {cat }} / K_{\mathrm{m}}$ ratios (Table 1 ). The structural basis for these kinetics results is discussed below.

Another assessment of the relative affinity of carboxylate and amide for the acceptor site can be achieved by studying the transfer of an acyl group to amine acceptors from a standard donor. The aminolysis of an acyl-enzyme intermediate should pass through the same transition states and tetrahedral intermediate as those from hydrolysis of the original amide (Scheme 5).

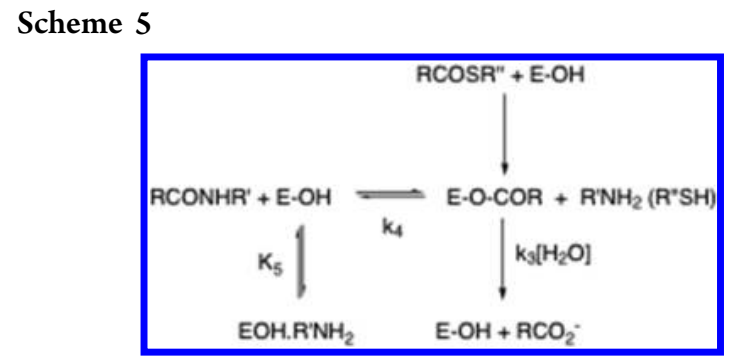

The acyl-enzyme intermediate, however, may be obtained from another source, hydrolysis of a thiolester, for example. In the case presented here, the steady state kinetics of aminolysis of thiolester 15 was studied. Hydrolysis of the acyl-enzyme intermediate from this substrate at saturation is probably ratedetermining with respect to thiolester hydrolysis because added amine nucleophiles accelerate the observed rate at substrate concentrations above $K_{\mathrm{m}}$. An example of this phenomenon is shown in Figure 2A. The results of such experiments, the determined $k_{4}$ values (Scheme 5), are listed in Table 2. Some amine acceptors at high concentrations also inhibited the reaction (an example is shown in Figure 2B), most likely by competition for the donor site (Scheme 5); this phenomenon has been previously observed. ${ }^{23,27}$ In such cases, values of $K_{5}$, usually quite large (millimolar), are also given in Table 2. 


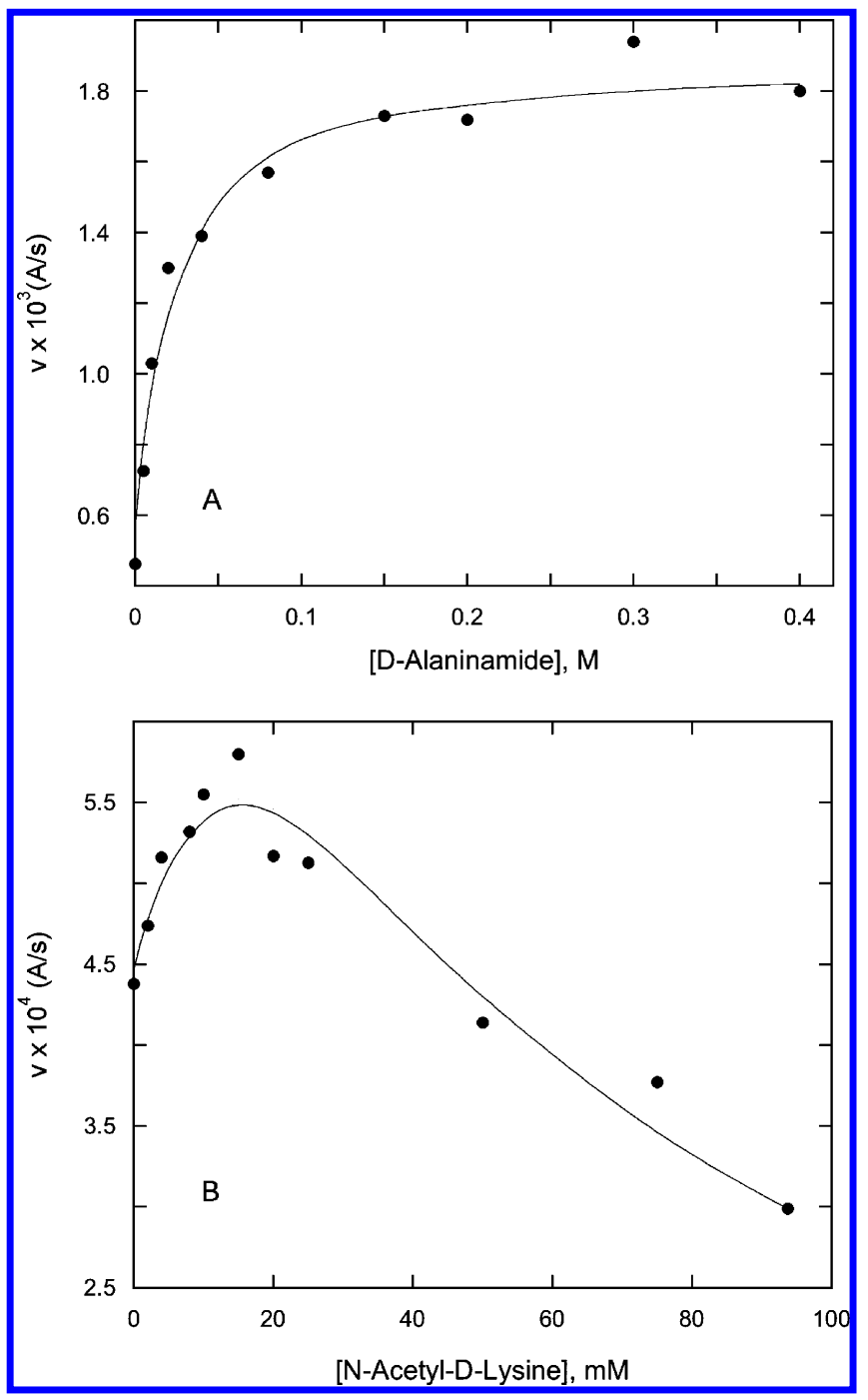

Figure 2. Effect of D-alaninamide (A) and N-E-acetyl-D-lysine (B) on initial rates of turnover of the thiolester $15(0.5 \mathrm{mM})$, catalyzed by PBP4a $(0.17 \mu \mathrm{M})$. The points are experimental, and the lines represent the fits of the data to Scheme 5 (see the text).

Evident from Table 2 is the much greater efficiency of $D$ amino acid amides than D-amino acids in reaction with the acyl-enzyme intermediate derived from reaction of $\mathbf{1 5}$ with PBP4a. D-Lysinamide, the closest analogue to a "real" acceptor (Figure 1), is particularly effective. The greater effectiveness of the amide acceptor is more evident in Table 2 than in Table 1. It may be that the diamide $\mathbf{1 8}$ would be an even better PBP4a substrate than 2, 4, or 5. Further extension of the carboxamide by N-substitution seemed unlikely to produce acyl acceptors; Dalanyl-D-alanine, for example (Table 2), was only a weak inhibitor. We are unaware of a bacterial peptidoglycan in which amidated diaminopimelic acid is extended through the amide.

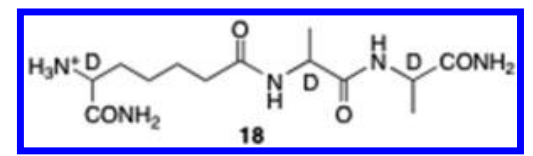

In contrast to the results for PBP4a, the R39 enzyme employed D-amino acid amide acceptors much less effectively than the amino acids themselves (Table 2). These results for both enzymes are thus in accord with those from the peptide hydrolysis experiments described above (Table 1).
Table 2. Kinetic Parameters for the Aminolysis of 15, Catalyzed by PBP4a and the R39 DD-Peptidase

\begin{tabular}{|c|c|c|c|}
\hline enzyme & amine $^{a}$ & $k_{4}\left(\mathrm{~s}^{-1} \mathrm{M}^{-1}\right)$ & $K_{5}(\mathrm{mM})$ \\
\hline \multirow[t]{12}{*}{ PBP4a } & D-alanine $(300)$ & $63 \pm 1.5$ & $130 \pm 16$ \\
\hline & D-alaninamide $(400)$ & $1100 \pm 220$ & $\mathrm{no}^{b}$ \\
\hline & D-alanyl-D-alanine (280) & no $^{b}$ & $50 \pm 12$ \\
\hline & D-phenylalanine $(80)$ & no $^{b}$ & $35 \pm 3$ \\
\hline & D-phenylalaninamide (84) & $720 \pm 180$ & no $^{b}$ \\
\hline & glycine $(500)$ & no $^{b}$ & $300 \pm 20$ \\
\hline & glycinamide (700) & $640 \pm 300$ & no $b$ \\
\hline & $\varepsilon$-N-acetyl-D-lysine (94) & $490 \pm 95$ & $23.4 \pm 1.5$ \\
\hline & D-lysine (25) & $(3.9 \pm 1.8) \times 10^{3}$ & no $^{b}$ \\
\hline & D-lysinamide (16) & $(3.2 \pm 1.4) \times 10^{4}$ & $\mathrm{no}^{b}$ \\
\hline & $\begin{array}{l}\text { D- } \alpha \text {-aminopimelic acid } \\
\quad(12.5)\end{array}$ & $150 \pm 2$ & no $^{b}$ \\
\hline & $\begin{array}{l}\text { meso-2,6-diaminopimelic acid } \\
\quad(40)\end{array}$ & $890 \pm 200$ & $15.8 \pm 0.3$ \\
\hline \multirow[t]{6}{*}{ R39 } & D-alanine (300) & $150 \pm 74$ & $75 \pm 27$ \\
\hline & D-alaninamide $(450)$ & $49 \pm 16$ & no $^{b}$ \\
\hline & D-phenylalanine (80) & $(7.1 \pm 2.3) \times 10^{3}$ & $\mathrm{no}^{b}$ \\
\hline & D-phenylalaninamide & $17 \pm 3$ & no $^{b}$ \\
\hline & glycine (500) & $360 \pm 100$ & no $b$ \\
\hline & glycinamide & $23 \pm 25$ & no $b$ \\
\hline
\end{tabular}

${ }^{a}$ Highest concentration in parentheses. ${ }^{b}$ Not observed under the conditions employed.

Another window into the specificity of the acceptor site can be obtained by consideration of the relative reactivities of penicillin V (16) and its amide (17) with these enzymes (Table 3 ). It is now accepted that $\beta$-lactams such as penicillins are

Table 3. Second-Order Acylation Rate Constants for Inhibition of PBP4a and the R39 DD-Peptidase by $\beta$-Lactams

\begin{tabular}{lll}
$\beta$-lactam & \multicolumn{1}{c}{ PBP4a } & \multicolumn{1}{c}{ R39 } \\
16 & $(1.83 \pm 0.33) \times 10^{5}$ & $(2.17 \pm 0.30) \times 10^{5}$ \\
17 & $(4.23 \pm 0.02) \times 10^{3}$ & $(9.1 \pm 3.0) \times 10$ \\
$17 / 16$ & 0.023 & 0.00042
\end{tabular}

inhibitors of DD-peptidases to a considerable degree because of their resemblance to D-Ala-D-Ala-terminated peptides. ${ }^{28,29}$ Thus, one might expect the carboxylate of a penicillin to bind at the active side of a DD-peptidase in the same position as that of the terminal carboxylate of a substrate. Crystal structures generally support this proposition, at least as far as one can judge from inert acyl-enzyme structures. ${ }^{10,30}$

The data of Table 3 show that penicillin $\mathrm{V}$ is an excellent inhibitor of both PBP4a and the R39 DD-peptidase. In the acylation transition state, the carboxylate group of 16 must fit well into the active site of both enzymes. As generally expected from precedent, ${ }^{31,32}$ the amide $\mathbf{1 7}$ is a considerably poorer inhibitor of both enzymes, but as anticipated from the results described above, it is a relatively much better inhibitor of PBP4a than of the R39 DD-peptidase.

The structural basis of the different specificities of PBP4a and the R39 DD-peptidase for amidated substrates was explored by molecular modeling. Tetrahedral intermediate models, 19, derived from the substrates of $\mathbf{4 , 5}$, and 18 were constructed from the crystal structures of a boronate transition state analogue complex of the R39 DD-peptidase ${ }^{12}$ and an acylenzyme complex of PBP4a. ${ }^{13}$ The initially constructed structures, where more than one orientation of the amide group was assessed, were subjected to molecular dynamics 
simulations as described in Materials and Methods. From these, structures exhibiting the most favorable interactions with the respective enzymes were selected for energy minimization, using interaction energy calculations ${ }^{33}$ to subsequently choose between them, where appropriate.

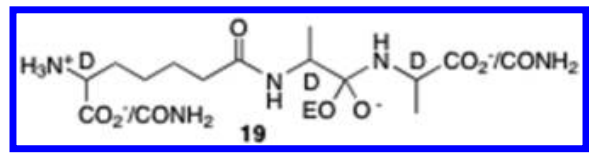

The active sites of PBP4a and the R39 DD-peptidase are very similar and would be expected to interact with substrates and their analogues in similar ways. ${ }^{12,13,34}$ In each case, there is a strongly interacting oxyanion hole comprising two backbone NH groups [Ser52 (49) and Thr413 (414); the residue number of PBP4a is followed in parentheses by that of the corresponding residue in the R39 DD-peptidase], which is believed to stabilize anionic tetrahedral intermediates.

All models were initially constructed such that the tetrahedral oxyanion occupied the oxyanion hole, and those interactions were, in general, retained. In certain cases, contact between the ligand and the oxyanion hole was lost during the molecular dynamics run; such structures were considered nonproductive. Other active site functional groups that either interact with specific substrates or are believed to be directly involved in catalysis are listed in Table 4, where they are subdivided into

Table 4. Active Site Residues of PBP4a and the R39 DDPeptidase in Contact with Specific Substrates

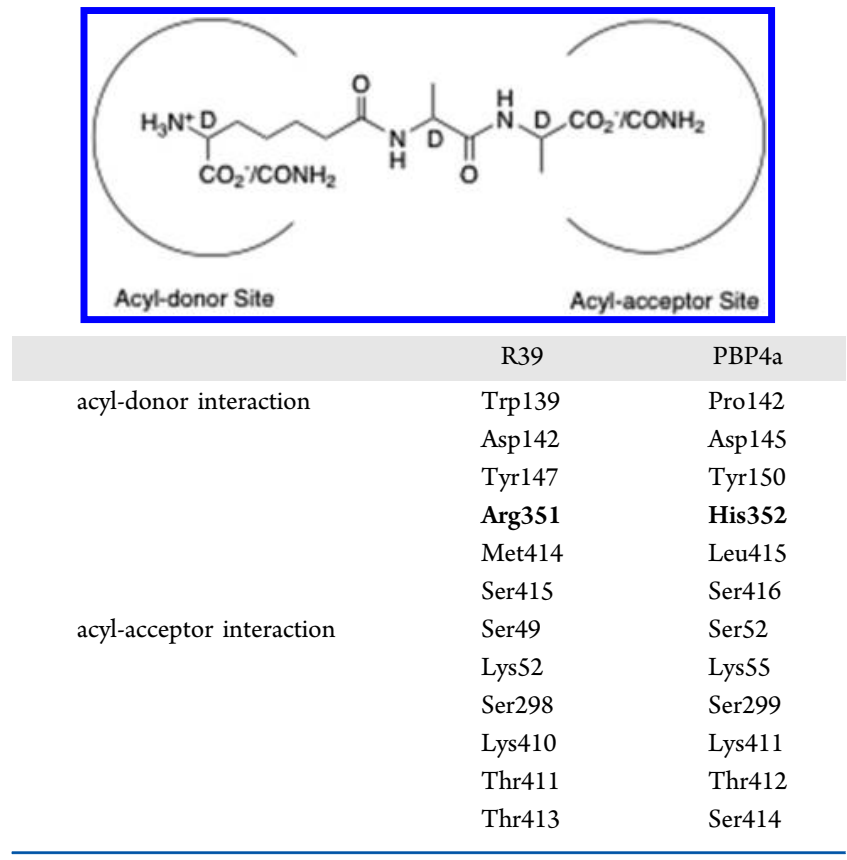

those interacting with the acyl-donor segment of the substrate and those interacting with the acyl-acceptor/leaving group. The details of these interactions and their putative participation in catalysis have been discussed previously. ${ }^{12,13}$

The superimposition diagram of Figure 3 emphasizes the point made above concerning the similarity of the PBP4a and R39 DD-peptidase active sites. Two differences in active site residues between them, whose interactions with substrates might change on amidation of the latter ( $\mathbf{1 a}$ vs $\mathbf{1 b}$ ), are apparent in Table 4 and Figure 3. The replacement of Thr413 in the R39 DD-peptidase with serine (414) in PBP4a may affect

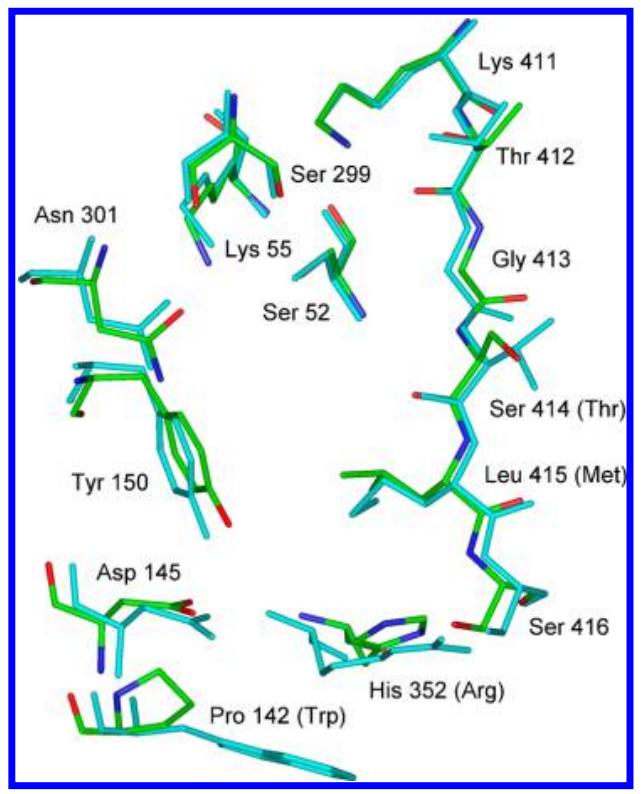

Figure 3. Superimposition of the backbone atoms of the active site residues of PBP4a (atomic colors) onto those of the R39 DD-peptidase (turquoise). Only heavy atoms are shown.

interaction with 4 because the terminal carboxylate groups of $\beta$ lactams $^{34}$ and, most likely, substrates ${ }^{12}$ interact with both Thr411 and Thr413 of the R39 DD-peptidase, and with their analogues in other PBP structures. ${ }^{3}$ It seems unlikely, however, that the mutation of Thr413 is specific for carboxamide binding because the equivalent of Ser413 is found in most LMMC enzymes, e.g., in Escherichia coli and other Gram-negative species where diaminopimelic acid amidation does not usually occur. More striking is the replacement of $\operatorname{Arg} 351$ with histidine (His352) in the acyl-donor site. The side chain of histidine, of course, may be cationic, like that of arginine, or neutral, depending on its $\mathrm{pK}_{\mathrm{a}}$ and the $\mathrm{pH}$ of the medium.

To obtain evidence for the $\mathrm{p} K_{\mathrm{a}}$ of His352 of PBP4a, the variation of the $K_{\mathrm{i}}$ value of the product inhibitors 20 and 21 was determined as a function of $\mathrm{pH}$ (Table 5). The product $\mathbf{2 0}$

Table 5. Inhibition of PBP4a by 20 and 21 as a Function of pH

\begin{tabular}{cccc} 
& \multicolumn{3}{c}{$K_{\mathrm{i}}(\mathrm{mM})$} \\
\cline { 2 - 4 } inhibitor & $\mathrm{pH} 6.0$ & $\mathrm{pH} 7.5$ & $\mathrm{pH} 8.8$ \\
20 & $0.9 \pm 0.1$ & $0.28 \pm 0.08$ & $0.48 \pm 0.08$ \\
21 & $>5$ & $0.24 \pm 0.06$ & $0.38 \pm 0.04$ \\
\hline
\end{tabular}

from 2 is known to occupy the donor site of the R39 DDpeptidase $^{11}$ and is likely to do so for PBP4a also. ${ }^{13}$ The $K_{\mathrm{i}}$ value of neither $\mathbf{2 0}$ nor $\mathbf{2 1}$ shows significant variation between $\mathrm{pH} 7.5$ and 8.8. This suggests the absence of a $\mathrm{p} K_{\mathrm{a}}$ of His 352 in this region, and thus the likelihood that its $\mathrm{p} K_{\mathrm{a}}$ is below 7.5. The increase in $K_{\mathrm{i}}$ for 20 at $\mathrm{pH} 6.0$ probably reflects the influence of

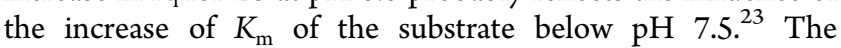
apparently greater increase in $K_{\mathrm{i}}$ of $\mathbf{2 1}$ than 20 suggests that the former inhibitor binds even more weakly to the protonated form of the enzyme than does the latter. These data are interpreted to mean that His352 contains a neutral imidazole moiety at neutral $\mathrm{pH}$. The structural models below, taken together with the kinetic data provided above, support this proposition. 
<smiles>CCCCCC(NC(=O)[C@H](C)NC(=O)CCCC[C@H](N)C(=O)O)C(N)=O</smiles>

Figure 4 shows structures of peptides 4 (Figure 4A) and 5 (Figure 4B) in the PBP4a active site where His352 is presumed to be neutral. These models show that both the $\mathrm{CO}_{2}{ }^{-}$and $\mathrm{CONH}_{2}$ groups interact well with the acyl-donor site. The carboxylate of 5 interacts directly [potential hydrogen bonds (see Figure 4B)] with Ser416, with both the $\mathrm{NH}$ and the $\mathrm{OH}$ moieties. It does not seem to interact significantly with His 352 On the other hand, the carboxamide of 4 interacts $(\mathrm{NH}-\pi)$ with the neutral imidazole of His352 (Figure 4A). If His352 were cationic, however, the carboxylate of $\mathbf{5}$ would interact tightly with it (electrostatic) but the amide of 4 less so (Figure 5). The structure in Figure 5 also shows the distortion of the $\beta-3$ strand (which supports one element of the oxyanion hole) that occurs throughout the molecular dynamics simulation. This suggests protein-mediated interaction between the acyl-donor and -acceptor sites, an issue that has previously been raised from

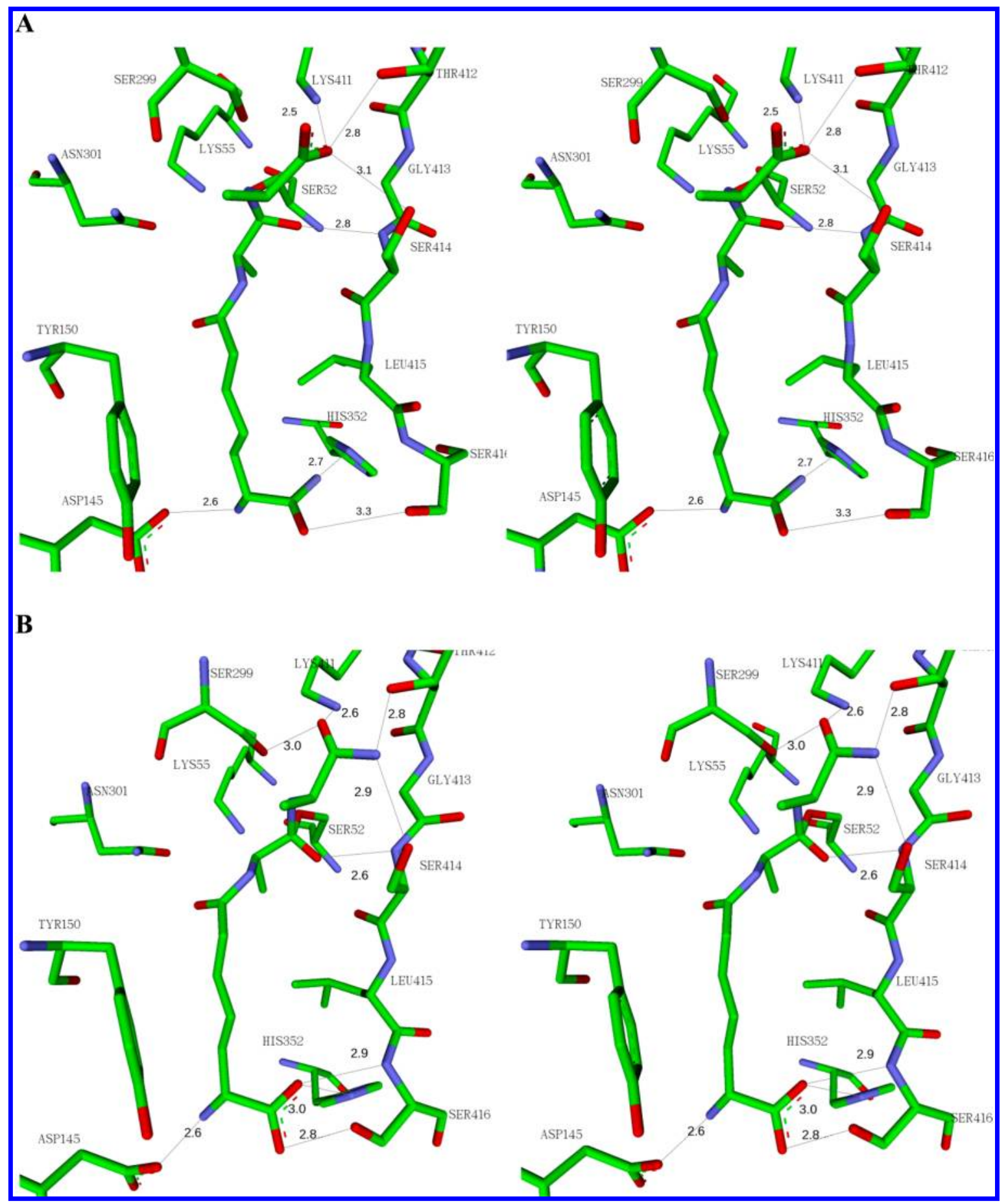

Figure 4. Stereoviews of energy-minimized tetrahedral intermediate structures (19) formed upon reaction of specific tripeptide substrates with PBP4a. The side chain of His352 is neutral. Only heavy atoms are shown except for hydrogens on the imidazole nitrogens of His352. (A) Peptide 4 and (B) peptide 5 . 


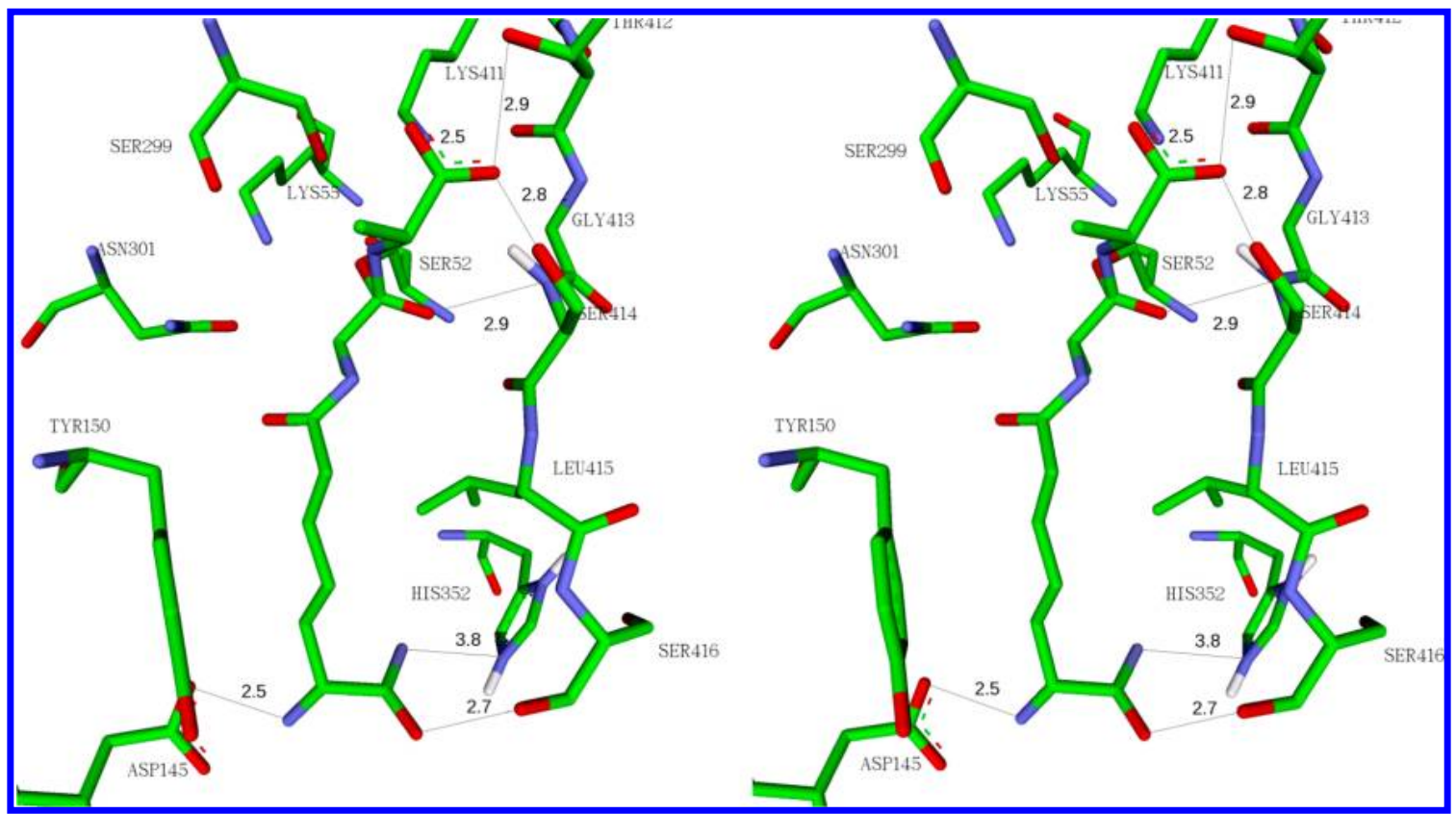

Figure 5. Stereoview of an energy-minimized tetrahedral intermediate structure (19) formed upon reaction of the specific tripeptide substrate 4 with PBP4a. The side chain of His352 is protonated and thus cationic. Only heavy atoms are shown except for hydrogens on the imidazole nitrogens of His352.

observations of crystal structures containing specific substrates. ${ }^{35}$ The analogous R39 DD-peptidase models (Figure S1 of the Supporting Information) also seem to show a less effective interaction of the amide of 4 than the carboxylate of 5 with the cationic (Arg351) donor site. Hence, the replacement of Arg351 of the R39 DD-peptidase, which in vivo would only come into contact with carboxylate substrates, with the neutral (at $\mathrm{pH}$ 7) imidazole of His352 of PBP4a appears to be a substitution favored by evolution to produce an enzyme that might have to process both carboxylate and amidated substrates. Models containing diamide 18 also show a snug fit into the enzyme active site when the histidine is neutral (Figure S2 of the Supporting Information). Figure 4B also shows that the amide group of $\mathbf{5}$ interacts well in the acceptor site, with apparent hydrogen bonds to the side chains of Ser299, Lys411, and Ser414.

Arg351 of the R39 DD-peptidase appears to be essentially completely conserved through LMMC DD-peptidases, most of which interact with peptidoglycan carboxylates. FASTA searches suggest that the histidine mutation is largely confined to Bacillus sp. where diaminopimelate amidation might be expected. ${ }^{14,36}$ A variety of other enzymes are required to distinguish carboxylate and carboxamide groups, and many of them use a strategy similar to that described above. For example, certain amino acid aminotransferases employ an arginine to accommodate a substrate $\gamma$-carboxylate and neutral ligands to accommodate an analogous $\gamma$-amide. ${ }^{37}$ The class I $E$. coli glutaminyl-tRNA synthetase employs neutral ligands for the substrate $\gamma$-amide but an arginine to divert a $\gamma$-carboxylate into a nonproductive complex. ${ }^{38}$ As an example, closer to home, orthologues of LMMA E. coli PBP5 and PBP6 appear to use a conserved arginine to bind the $\alpha$-glutamyl carboxylate of peptidoglycan substrates. ${ }^{39}$ On the other hand, orthologues of PBP3 of Streptococcus pneumoniae, also LMMA DD-peptidases, seem to have neutral ligands in the analogous position to interact with the $\alpha$-glutaminyl carboxamides of their peptidoglycan.
The results described above strongly suggest that the PBP4a DD-peptidase of $B$. subtilis is adapted to efficiently catalyze reactions of peptidoglycan fragments containing both $\mathrm{D}$ aminocarboxylate and D-aminocarboxamide termini. In vivo, therefore, this enzyme may well have a dual role, evolutionarily selected by the presence of both termini in the peptidoglycan of $B$. subtilis at different phases of growth. ${ }^{14,18}$ PBP4a is thought to generally act as an endopeptidase in vivo. ${ }^{4,25}$ In contrast, the R39 DD-peptidase, another LMMC enzyme, seems strongly adapted to a single peptidoglycan structure. In principle, inhibitor design could take advantage of the kind of dual specificity found in PBP4a to target particular enzymes or particular stages of the cell cycle. Design of DD-peptidase inhibitors based on specific elements of peptidoglycan structure remains an attractive goal, but not one easily achieved. ${ }^{3,40}$ The affinity of other B. subtilis PBPs, including the essential HMM enzymes, for carboxamide termini is an interesting issue, and one that we are currently investigating.

\section{ASSOCIATED CONTENT}

\section{S Supporting Information}

Synthetic details for the preparation of peptide 5 and Dlysinamide and structures of $\mathbf{2}$ and $\mathbf{4}$ bound to the Actinomadura R39 DD-peptidase and of $\mathbf{1 8}$ bound to B. subtilis PBP4a. This material is available free of charge via the Internet at http://pubs.acs.org.

\section{AUTHOR INFORMATION}

\section{Corresponding Author}

*Telephone: (860) 685-2629. E-mail: rpratt@wesleyan.edu. Fax: (860) 685-2211.

\section{Funding}

This research was supported by National Institutes of Health Grant AI-17986 (R.F.P.) and in part by the Belgian Program on Interuniversity Poles of Attraction initiated by the Belgian State, 
Prime Minister's Office, Science Policy programming (IAP $\mathrm{n}^{\circ}$ P6/19). C.D. is a research associate of the FRS-FNRS, Belgium.

\section{Notes}

The authors declare no competing financial interest.

\section{ABBREVIATIONS}

DCM, dichloromethane; DIPEA, diisopropylethylamine; DMF, dimethylformamide; DMSO, dimethyl sulfoxide; EDC, $N$ [(dimethylamino)propyl]- $N^{\prime}$-ethylcarbodiimide; ESI/MS, electrospray ionization mass spectrometry; HATU, O-(7-azabenzotriazol-1-yl)- $N, N, N^{\prime}, N^{\prime}$-tetramethyluronium hexafluorophosphate; HMM, high-molecular mass; LMM, low-molecular mass; MES, 2-(N-morpholino)ethanesulfonic acid; MOPS, 3(morpholino)propanesulfonic acid; NMR, nuclear magnetic resonance; PBP, penicillin-binding protein; TAPS, $N$-tris(hydroxymethyl)methyl-3-aminopropanesulfonic acid; TFA, trifluoroacetic acid; THF, tetrahydofuran; TLC, thin-layer chromatography.

\section{REFERENCES}

(1) Waxman, D. J., and Strominger, J. L. (1983) Penicillin-binding proteins and the mechanism of action of $\beta$-lactam antibiotics. Annu. Rev. Biochem. 52, 825-869.

(2) Macheboeuf, P., Contreras-Martel, C., Job, V., Dideberg, O., and Dessen, A. (2006) Penicillin-binding proteins: Key players in bacterial cell cycle and drug resistance processes. FEMS Microbiol. Rev. 30, 673691.

(3) Pratt, R. F. (2008) Substrate specificity of bacterial DD-peptidases (penicillin-binding proteins). Cell. Mol. Life Sci. 65, 2138-2155.

(4) Nemmara, V. V., Dzhekieva, L., Sarkar, K. S., Adediran, S. A., Duez, C., Nicholas, R. A., and Pratt, R. F. (2011) Substrate specificity of low-molecular mass bacterial DD-peptidases. Biochemistry 50, 10091-10101.

(5) Popham, D. L., and Young, K. D. (2003) Role of penicillinbinding proteins in bacterial cell morphogenesis. Curr. Opin. Microbiol. 6, 594-599.

(6) Matthei, P.-J., Neves, D., and Dessen, A. (2010) Bridging cell wall biosynthesis and bacterial morphogenesis. Curr. Opin. Struct. Biol. 20, $749-755$.

(7) Ghuysen, J.-M. (1991) Serine $\beta$-lactamases and penicillin-binding proteins. Annu. Rev. Microbiol. 45, 37-67.

(8) Leyh-Bouille, M., Nakel, M., Frère, J.-M., Johnson, K., Duez, C., Ghuysen, J.-M., Nieto, M., and Perkins, H. R. (1972) Penicillinsensitive DD-carboxypeptidases from Streptomyces strains R39 and K11. Biochemistry 11, 1290-1298.

(9) Ghuysen, J.-M., Leyh-Bouille, M., Campbell, J. N., Moreno, R. Frère, J.-M., Duez, C., Nieto, M., and Perkins, H. R. (1973) Structure of the wall peptidoglycan of Streptomyces R39 and the specificity and profile of its exocellular DD-carboxypeptidase-transpeptidase for peptide acceptors. Biochemistry 12, 1243-1251.

(10) McDonough, M. A., Anderson, J. W., Silvaggi, N. R., Pratt, R. F., and Kelly, J. A. (2002) Structures of two kinetic intermediates reveal species specificity of penicillin-binding proteins. J. Mol. Biol. 322, 111122.

(11) Sauvage, E., Powell, A. J., Heilemann, J., Josephine, H. R., Charlier, P., Davies, C., and Pratt, R. F. (2008) Crystal structures of complexes of bacterial DD-peptidases with peptidoglycan-mimetic ligands; the substrate specificity puzzle. J. Mol. Biol. 381, 383-393.

(12) Dzhekieva, L., Rocaboy, M., Kerff, F., Charlier, P., Sauvage, E., and Pratt, R. F. (2010) Crystal structure of a complex between the Actinomadura R39 DD-peptidase and a peptidoglycan-mimetic boronate inhibitor: Interpretation of a transition state analogue in terms of catalytic mechanism. Biochemistry 49, 6411-6419.

(13) Sauvage, E., Duez, C., Herman, R., Kerff, F., Petrella, S., Anderson, J. W., Adediran, S. A., Pratt, R. F., Frère, J.-M., and Charlier, P. (2007) Crystal structure of the Bacillus subtilis penicillin-binding protein $4 \mathrm{a}$ and its complex with a peptidoglycan-mimetic peptide. $J$. Mol. Biol. 371, 528-539.

(14) Atrih, A., Bacher, G., Allmaier, G., Williamson, M. P., and Foster, J. J. (1999) Analysis of peptidoglycan structure from vegetative cells of B. subtilis 168 and role of PBPs in peptidoglycan maturation. J. Bacteriol. 181, 3956-3966.

(15) Warth, A. D., and Strominger, J. L. (1971) Structure of the peptidoglycan from vegetative cell walls of Bacillus subtilis. J. Bacteriol. 180, 4967-4973.

(16) Warth, A. D., and Strominger, J. L. (1969) Structure of the peptidoglycan in bacterial spores: Occurrences of the lactam of muramic acid. Proc. Natl. Acad. Sci. U.S.A. 64, 528-535.

(17) Bernard, E., Rolain, T., Courtin, P., Hols, P., and ChapotCartier, M.-P. (2011) Identification of the amidotransferase AsnB1 as being reasonable for meso-diaminopimelic acid amidation in Lactobacillus plantarum peptidoglycan. J. Bacteriol. 193, 6323-6330.

(18) Pederson, L. B., Murray, T., Popham, D. L., and Setlow, P. (1998) Characterization of $\mathrm{dacC}$, which encodes a new low-molecular weight penicillin-binding protein in Bacillus subtilis. J. Bacteriol. 180, 4967-4973.

(19) Scheffers, D.-J. (2005) Dynamic localization of penicillinbinding proteins during spore development in Bacillus subtilis. Microbiology 151, 999-1012.

(20) Anderson, J. W., Adediran, S. A., Charlier, P., Nguyen-Distèche, M., Frère, J.-M., Nicholas, R. A., and Pratt, R. F. (2003) On the substrate specificity of bacterial DD-peptidases: Evidence from two series of peptidoglycan-mimetic peptides. Biochem. J. 373, 949-955.

(21) Johnson, D. A. (1953) Carboxy derivatives of benzylpenicillin. J. Am. Chem. Soc. 75, 3636-3637.

(22) Xu, Y., Soto, G., Adachi, H., Van der Linden, M. P. G., Keck, W., and Pratt, R. F. (1994) Relative specificities of a series of $\beta$-lactamreognizing enzymes towards the side chains of penicillins and acyclic thioldepsipeptides. Biochem. J. 302, 851-856.

(23) Adediran, S. A., Kumar, I., Nagarajan, R., Sauvage, E., and Pratt, R. F. (2011) Kinetics of reactions of the Actinomadura R39 DDpeptidase with specific substrates. Biochemistry 50, 367-387.

(24) Kuzmic, P. (1996) Program DYNAFIT for the analysis of enzyme kinetic data: Application to HIV proteinase. Anal. Biochem. 237, 260-273.

(25) Duez, C., Zervosen, A., Teller, N., Melkonian, R., Banzubazé, E., Bouillenne, F., Luxen, A., and Frère, J.-M. (2009) Characterization of the proteins encoded by the Bacillus subtilis yoxA-dacC operon. FEMS Microbiol. Lett. 300, 42-47.

(26) Shimshock, S. S., Waltermire, R. E., and DeShong, P. (1991) A total synthesis of ( \pm )-tirandamycin B. J. Am. Chem. Soc. 113, 87918796.

(27) Kumar, I., and Pratt, R. F. (2005) Transpeptidation of a specific substrate catalyzed by the Streptomyces R61 DD-peptidase: Characterization of a chromogenic substrate and acyl acceptor design. Biochemistry 44, 9971-9979.

(28) Tipper, D. J., and Strominger, J. L. (1965) Mechanism of action of penicillins: A proposal based on their structural similarity to acyl-Dalanyl-D-alanine. Proc. Natl. Acad. Sci. U.S.A. 54, 1133-1141.

(29) Pratt, R. F. (2002) Functional evolution of the serine $\beta$ lactamase active site. J. Chem. Soc., Perkin Trans. 2, 851-861.

(30) Silvaggi, N. R., Josephine, H. R., Kuzin, A. P., Nagarajan, R. Pratt, R. F., and Kelly, J. A. (2005) Crystal structures of complexes between the R61 DD-peptidase and peptidoglycan-mimetic $\beta$-lactams: A non-covalent complex with a "perfect penicillin". J. Mol. Biol. 345, 521-533.

(31) Holysz, R. P., and Stavely, H. E. (1950) Carboxy derivatives of benzylpenicillin. J. Am. Chem. Soc. 72, 4760-4763.

(32) Varetto, L., DeMeester, F., Monnaie, D., Marchand-Brynaert, J., Dive, G., Jacob, F., and Frère, J.-M. (1991) The importance of the negative charge of $\beta$-lactam compounds in the interactions with activesite serine DD-peptidases and $\beta$-lactamases. Biochem. J. 278, 801-807.

(33) Curley, K. C., and Pratt, R. F. (1997) Effectiveness of tetrahedral adducts as transition-state analogs and inhibitors of the class $\mathrm{C} \beta$ - 
lactamase of Enterobacter cloacae P99. J. Am. Chem. Soc. 119, 15291538.

(34) Sauvage, E., Herman, R., Petrella, S., Duez, C., Bouillenne, F., Frère, J.-M., and Charlier, P. (2005) Crystal structure of the Actinomadura R39 DD-peptidase reveals new domains in penicillin binding proteins. J. Biol. Chem. 280, 31249-31256.

(35) Silvaggi, N. R., Anderson, J. W., Brinsmade, S. A., Pratt, R. F., and Kelly, J. A. (2003) The crystal structure of phosphonate-inhibited D-Ala-D-Ala peptidase reveals an analogue of a tetrahedral transition state. Biochemistry 42, 1199-1208.

(36) Hughes, R. C. (1970) Autolysis of isolated cell walls of Bacillus licheniformis N.C.T.C.6346 and Bacillus subtilis Marburg strain 168. Separation of the products and characterization of the mucopeptide fragments. Biochem. J. 119, 849-860.

(37) Hirotsu, K., Goto, M., Okamoto, A., and Miyahara, I. (2005) Dual substrate recognition of aminotransferases. Chem. Rec. 5, 160172.

(38) Bullock, T. L., Uter, N., Nissan, T. A., and Perona, J. J. (2003) Amino acid discrimination by a class I aminoacyl-tRNA synthetase specified by negative determinants. J. Mol. Biol. 328, 395-408.

(39) Chen, Y., Zhang, W., Shi, Q., Hesek, D., Lee, M., Mobashery, S., and Shoichet, B. K. (2009) Crystal structures of penicillin-binding protein 6 from Escherichia coli. J. Am. Chem. Soc. 131, 14345-15354. (40) Josephine, H. R., Charlier, P., Davies, C., Nicholas, R. A., and Pratt, R. F. (2006) Reactivity of penicillin-binding proteins with peptidoglycan-mimetic $\beta$-lactams: What's wrong with these enzymes? Biochemistry 45, 15873-15883. 